Dokuz Eylül Üniversitesi-Mühendislik Fakültesi

Fen ve Mühendislik Dergisi

Cilt 20, Sayı 60, Eylül, 2018
Dokuz Eylul University-Faculty of Engineering Journal of Science and Engineering Volume 20, Issue 60, September, 2018

DOI: $10.21205 /$ deufmd. 2018206078

\title{
The Gokceada Island (Northwest of Turkey) Earthquake of $M w 6.5$ on 24 May 2014: Strong-Motion Examinations
}

\author{
Elçin GÖK ${ }^{* 1}$ \\ 1Dokuz Eylul University, Engineering Faculty, Department of Geophysics, 35160,Izmir.
} (ORCID: 0000-0002-2643-1453)

(Alınış / Received: 30.01.2018, Kabul / Accepted: 20.06.2018, Online Yayınlanma / Published Online: 15.09.2018)

Keywords
Site effect,
amplification,
Gokceada Island
earthquake,
accelerometer.

Abstract: This paper aims to study the Gokceada Island earthquake from an engineering seismological point of view. On May 24, 2014, a large earthquake of magnitude 6.5 occurred in the Northwest of Turkey. The highest recorded peak ground acceleration is at Gokceada Island station. The evaluation of site amplification effects has been carried out, using the data from the main shock and aftershocks of the earthquake. For each site, the standard spectral ratio (SSR) and horizontal to vertical spectral ratio (H/V) methods were calculated for 29 strong motion stations. The results show a clear influence of the site soil conditions on the amplification of ground motion. Furthermore, the peak ground acceleration (PGA) study was performed using attenuation relationships at 53 location sites to find out how they were affected by the ground motion. The highest PGA value was found near the epicenter, and it's attenuated with distance. We used some ground motion prediction equations to compare observed PGA values at stations with them. The measured values were significantly higher than the prediction models.

\section{Mayıs 2014, Mw 6.5 Gökçeada (Kuzeybatı Türkiye) Depremi: Kuvvetli Yer Hareketi Çalışmaları}

\footnotetext{
Anahtar Kelimeler Özet: $\mathrm{Bu}$ çalışma, Gökçeada depremini mühendislik sismolojisi Zemin etkisi, açısından incelemeyi amaçlamaktadır. 24 Mayıs 2014' de, büyütme, Gökçeada Türkiye'nin kuzeybatısında 6.5 büyüklüğünde bir deprem depremi, meydana geldi. En yüksek yer ivmesi, Gökçeada istasyonunda ivme-ölçer. kaydedilmiştir. Zemin büyütme etkilerinin değerlendirilmesi için depremin ana şok ve artçı sarsıntılarından elde edilen veriler kullanılmıştır. Depremi kaydeden 29 adet ivme-ölçer istasyonunda standart spektral oran ve yatay-düşey spektral oran yöntemleri kullanılarak hesaplama yapılmıştır. Sonuçlar, yer hareketinin zeminler üzerindeki net bir etkisini göstermektedir. Ayrıca depremi kaydeden 53 yerleşim yerindeki en büyük yer ivmesi 
değerleri azalım ilişkileri kullanılarak incelenmiştir. En büyük yer ivme değeri merkez üssün yakınında bulunmuş ve mesafeye bağlı olarak azaldığı gözlenmiştir. Bazı yer hareketi tahmin modelleri kullanarak, ölçülen değerlerle modelleri karşılaştırdığımızda istasyonlarda ölçülen değerler tahmin modellerinden oldukça yüksek çıkmıştır.

\section{Introduction}

The area struck by the earthquake, located in the northwestern Turkey, has undergone a wide scale extension through the peculiarity of the Aegean Region [1] and this area was also affected by North Anatolian Fault zone.

The correlation of structural damage with local site geology and soil properties is commonly observed after a strong earthquake. This may implicitly measure the relation between groundmotion characteristics and local site conditions. Seismic microzonation, urban planning, land-use management, and mitigation of urban earthquake risk require assessment of site effects in earthquake-prone urban areas [2] Izmir and its surroundings are defined as a microseismically active area [3,4]; therefore, available strong-motion events in Izmir are not adequate to study the local site effects. For this reason, all strong motion stations triggered by Gokceada Island earthquake including IzmirNET stations are used [5].

As announced by the AFAD-Turkey Earthquake Data Center (AFAD, http://www.deprem.gov.tr), which belongs to the Disaster and Emergency Management Presidency of Turkish Republic, the 24 May 2014 Gokceada Island earthquake (09h25 GMT) hit the Northwest of Turkey. The largest aftershock $(M w=5.3)$ was six minutes later $(09 \mathrm{~h} 31)$ following the mainshock, and located at the $\mathrm{NE}$ end of the activation zone; in Figure 1 . the epicenters of the 8 events with $M w>4$ are plotted, and their source parameters are given in Table 1.

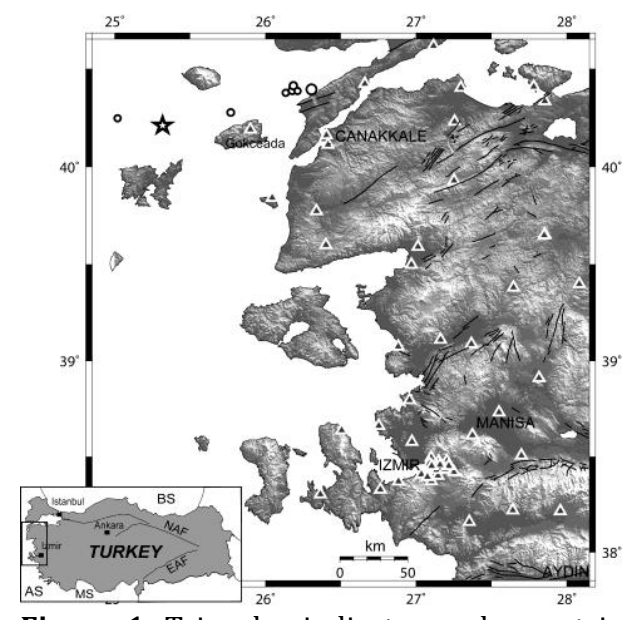

Figure 1. Triangles indicate accelerometric array used in this study. Thick lines represent faults. Inset Map: AS is the Aegean Sea, BS is the Black Sea, EAF is the East Anatolian Fault, MS is the Mediterranean Sea, and NAF is the North Anatolian Fault Zone. Epicenters are shown with circles.

In the Marmara and Aegean Region, primarily in Istanbul, Canakkale, and Edirne, the earthquake was also felt as severe. Major damage in 228 houses (163 in Gokceada Island, and 65 in Gallipoli Peninsula) was notified by AFAD. Other 49 residences suffered moderate or light damage, which did not cause any casualties. According to the seismic data, the focal depth of the event was estimated at $25 \mathrm{~km}$ (AFAD), and the moment tensor solutions of the mainshock reveal strike-slip faulting. The event can be associated with North Anatolian Fault Zone (NAFZ). NAFZ in the Marmara Sea after 1999 earthquake 
implies a high seismic risk for Istanbul local topography and soil type were and its vicinity.

In this paper, the site response and PGA study affected by Gokceada Island earthquake were studied. The effects of investigated. Furthermore, SSR and H/V solutions for the main-shock were compared.

Table 1. Parameters for the earthquakes used in this study. Location parameters are taken from the AFAD Presidency of Earthquake Directorate (DDB) in Ankara.

\begin{tabular}{|c|c|c|c|c|c|c|}
\hline $\begin{array}{c}\text { Event } \\
\text { Number }\end{array}$ & $\begin{array}{c}\text { Date } \\
\text { (GMT) }\end{array}$ & $\begin{array}{c}\text { Latitude } \\
\left(\mathbf{N}^{\circ}\right)\end{array}$ & $\begin{array}{c}\text { Longitude } \\
\left(\mathbf{E}^{\circ}\right)\end{array}$ & $\begin{array}{c}\text { Depth } \\
(\mathbf{k m})\end{array}$ & Type & Magnitude \\
\hline $1^{*}$ & $24 / 05 / 201409.25$ & 40.2108 & 25.3073 & 25 & $\mathrm{M}_{\mathrm{w}}$ & 6.5 \\
\hline 2 & $24 / 05 / 201409.31$ & 40.3951 & 26.3058 & 7 & $\mathrm{M}_{\mathrm{w}}$ & 5.3 \\
\hline 3 & $24 / 05 / 201410.11$ & 40.3888 & 26.1786 & 19 & $\mathrm{M}_{\mathrm{w}}$ & 4.6 \\
\hline 4 & $24 / 05 / 201411.18$ & 40.3861 & 26.2146 & 26 & $\mathrm{M}_{\mathrm{L}}$ & 4 \\
\hline 5 & $24 / 05 / 201411.33$ & 40.2765 & 25.7700 & 15 & $\mathrm{M}_{\mathrm{w}}$ & 4.5 \\
\hline 6 & $24 / 05 / 201415.01$ & 40.3770 & 26.1345 & 15 & $\mathrm{M}_{\mathrm{w}}$ & 4 \\
\hline 7 & $25 / 05 / 201411.38$ & 40.4128 & 26.1851 & 21 & $\mathrm{M}_{\mathrm{w}}$ & 4.8 \\
\hline 8 & $26 / 05 / 201421.28$ & 40.2476 & 25.0200 & 15 & $\mathrm{M}_{\mathrm{w}}$ & 4.1 \\
\hline
\end{tabular}

* Mainshock

\section{Material and Method}

For this paper, all strong-motion data set consists of accelerometric data recorded by AFAD strong motion database. 17 continuous stations, which are called IzmirNET [5] and 12 triggered stations, were used for the investigation of site effects. Furthermore, the PGA of the ground motion was calculated, and four different ground motion prediction equations (GMPE) of mainshock for extra 23 stations around the study area with Joyner-Boore distances (RJB) [6] between 0 and $100 \mathrm{~km}$ were compared.

53 strong motion stations are located at different geological sites. Some of the sites are classified according to the Eurocode 8 (EC8; Comité Européen de Normalisation 2004) based on the shearwave velocity averaged over the top 30 $\mathrm{m}$ of the soil profile, Vs30 (where EC8 class $\mathrm{A}>800 \mathrm{~m} / \mathrm{s}, \mathrm{B}=360-800 \mathrm{~m} / \mathrm{s}, \mathrm{C}=$ $180-360 \mathrm{~m} / \mathrm{s}$, and $D<180 \mathrm{~m} / \mathrm{s}$ ) in the last column of Table 2. The classes were determined by asterisks on the basis of geological/geophysical information obtained by Vs30 measurements conducted by AFAD. Most stations belong to class $\mathrm{C}$ or $\mathrm{D}$ while a few stations are classified as class A and B.

The accelerographs are generally Guralp CMG 5TD three-component instruments coupled with 24-bit digitizers and sampled at $100 \mathrm{~S} / \mathrm{s}$, and the other stations are GMSPlus (Table 2). Both stations were used after response effect was removed. The stations were installed by the different project with the aim of recording the strongest events and evaluating the effect of site conditions on the ground motion.

The mainshock $(M w=6.5)$ was recorded by 53 digital stations of the AFAD. The epicentral distances range from $51 \mathrm{~km}$ to about $321 \mathrm{~km}$. The largest PGA is 176,6 gal recorded at station Gokceada at the epicenter distance equal to $51 \mathrm{~km}$. The near-fault stations are characterized by vertical PGAs that are nearly the same as the horizontal PGAs. 


\subsection{Spectral ratios}

Only a limited portion of the records that contain predominantly $\mathrm{S}$ waves was used. The spectral shapes were smoothed, and the amplitude ratios with respect to the rock site (BYR) were calculated.

To quantify the site characteristics of all station locations, both SSR and H/V spectral ratio techniques were used. The SSR is considered to be a very reliable method to estimate site effects.

After being introduced by [7], these two methods have been widely used and discussed in the literature by many researchers around the world as [2, 8 13].

Firstly, the SSR method from the eight earthquakes was used to obtain the relative amplification between the two sites. The critical assumption in the spectral-ratio method is that the two sites share the same source spectrum and have comparable propagation path effects for the phases included in the sample window. For the narrow range of azimuths and epicentral distances that are covered by our data, all effects of radiation pattern should be minimal. On the basis of these assumptions, the source and path effects are eliminated by taking the spectral ratios of sample windows when the distance to the reference site is small compared with the source to site distance. The technique also assumes that the reference site is transparent and has no site complexity of its own. The calculation of spectral ratios from weak motion records is one of the most frequently applied techniques for the estimation of site response. In practice, this method consists of taking the spectral ratio between the site of interest and a nearby hard-rock (reference) site. In some cases, a suitable hard-rock reference site may not be available close to the site of interest. In this case, the horizontal component of the earthquake is proportional to the vertical component of the earthquake that is assumed not affected by local ground conditions [14, $15]$.

Table 2. Parameters of the 24 May $2014 M w 6.5$ Gokceada Island (Northwestern of Turkey) Earthquake. The asterisks sign indicates the site conditions.

\begin{tabular}{|c|c|c|c|c|c|c|c|}
\hline No & Code & Station Name & Lat $\left(\mathbf{N}^{\circ}\right)$ & $\overline{\text { Long }\left(\mathrm{E}^{\circ}\right)}$ & PGA & $\overline{R_{\text {epi }}(\mathbf{k m})}$ & $\mathrm{Vs30}(\mathrm{m} / \mathrm{s})$ \\
\hline 1 & 1711 & GOKCEADA & 40.19082 & 25.90783 & 176.6 & 51 & - \\
\hline 2 & 1708 & BOZCAADA & 39.8419 & 26.0528 & 31.48 & 76 & - \\
\hline 3 & 1701 & CCANAKKALE MERKEZ & 40.14145 & 26.39948 & 141.04 & 93 & 192 \\
\hline 4 & 1713 & ÇANAKKALE MRK-2 & 40.16216 & 26.41166 & 97.47 & 94 & - \\
\hline 5 & 1714 & KEPEZ & 40.11291 & 26.42205 & 51.12 & 95 & - \\
\hline 6 & 1704 & EZINE & 39.77388 & 26.34563 & 37.41 & 101 & 403 \\
\hline 7 & 1716 & AYVACIK & 39.59965 & 26.40761 & 55.33 & 116 & - \\
\hline 8 & 1710 & GELIBOLU & 40.42334 & 26.66715 & 123.15 & 118 & 286 \\
\hline 9 & 5904 & $\begin{array}{l}\text { SARKOY } \\
\end{array}$ & 40.61485 & 27.12256 & 86.32 & 160 & 225 \\
\hline 10 & 1013 & EDREMIT & 39.58952 & 27.01924 & 46.94 & 162 & 223 \\
\hline 11 & 1019 & BURHANIYE & 39.49815 & 26.97546 & 31.63 & 164 & - \\
\hline 12 & 1703 & $\overline{\text { BíGA }}$ & 40.23182 & 27.26288 & 36.32 & 166 & $\overline{304}$ \\
\hline 13 & 1707 & YENICE & 39.92916 & 27.25908 & 49.37 & 169 & 324 \\
\hline 14 & 1712 & KARABIGA & 40.40396 & 27.30349 & 47.7 & 170 & 683 \\
\hline 15 & 3503 & IZMIRNET-DKL & 39.0739 & 26.88834 & 41.55 & 186 & 193 \\
\hline 16 & 3537 & BERGAMA & 39.10957 & 27.17064 & 10.87 & 202 & - \\
\hline 17 & 3527 & KARABURUN & 38.63903 & 26.51277 & 11.94 & 204 & - \\
\hline 18 & 1018 & ERDEK & 40.40885 & 27.78719 & 15.62 & 211 & - \\
\hline 19 & 3535 & $\overline{\text { ALIAGA }}$ & 38.79629 & 26.96323 & 8.77 & 213 & - \\
\hline
\end{tabular}



Examinations

\begin{tabular}{|c|c|c|c|c|c|c|c|}
\hline No & Code & Station Name & Lat $\left(\mathrm{N}^{\circ}\right)$ & Long $\left(\mathrm{E}^{\circ}\right)$ & PGA & $R_{\text {epi }}(\mathrm{km})$ & Vs30*(m/s) \\
\hline 20 & 3534 & FOCA & 38.66241 & 26.75856 & 12.72 & 213 & 328 \\
\hline 21 & 3526 & MENEMEN & 38.57823 & 26.9795 & 18.9 & 215 & - \\
\hline 22 & 1011 & EDINCIK & 40.33601 & 27.86104 & 28.49 & 217 & 330 \\
\hline 23 & 3508 & KINIK & 39.0883 & 27.37472 & 8.49 & 218 & 558 \\
\hline 24 & 1016 & SAVASTEPE & 39.38041 & 27.65438 & 15.48 & 222 & \\
\hline 25 & 1003 & BALIKESIR-MERKEZ & 39.65499 & 27.86204 & 29.44 & 227 & 460 \\
\hline 26 & 1017 & BALIKESIR-MERKEZ-2 & 39.64966 & 27.85715 & 30.5 & 227 & 662 \\
\hline 27 & 3528 & CESME & 38.30393 & 26.37256 & 4.92 & 232 & - \\
\hline 28 & 3523 & IZMIRNET-URL & 38.3282 & 26.7706 & 5.82 & 245 & 414 \\
\hline 29 & 1020 & SUSURLUK & 39.91714 & 28.16411 & 50.98 & 246 & - \\
\hline 30 & 3516 & IZMIRNET-GZL & 38.3706 & 26.8907 & 3.93 & 247 & 460 \\
\hline 31 & 3524 & IZMIRNET-YMN & 38.4969 & 27.1073 & 4.41 & 247 & 459 \\
\hline 32 & 3515 & IZMIRNET-BOS & 38.4649 & 27.094 & 10.26 & 249 & 171 \\
\hline 33 & 3510 & IZMIRNET-BLC & 38.409 & 27.043 & 7.05 & 251 & 313 \\
\hline 34 & 3514 & IZMIRNET-BYR & 38.4762 & 27.1581 & 4.34 & 251 & 836 \\
\hline 35 & 3519 & IZMIRNET-KSK & 38.4525 & 27.1112 & 12.69 & 251 & 131 \\
\hline 36 & 3513 & IZMIRNET-BYN & 38.4584 & 27.1671 & 15.77 & 253 & 196 \\
\hline 37 & 4501 & MANISA-MERKEZ & 38.61259 & 27.38138 & 6.13 & 253 & 340 \\
\hline 38 & 3506 & IZMIRNET-GZLY & 38.39443 & 27.08211 & 2.3 & 254 & 771 \\
\hline 39 & 3518 & IZMIRNET-KON & 38.4312 & 27.1435 & 13.26 & 254 & 298 \\
\hline 40 & 3520 & IZMIRNET-MNV & 38.478 & 27.2111 & 3.87 & 254 & 875 \\
\hline 41 & 4508 & SARUHANLI & 38.73237 & 27.55679 & 17.6 & 255 & - \\
\hline 42 & 3530 & IZMIRNET-BRN & 38.45302 & 27.22444 & 9.58 & 257 & 270 \\
\hline 43 & 3522 & IZMIRNET-CMD & 38.4357 & 27.1987 & 7.66 & 257 & 249 \\
\hline 44 & 3512 & IZMIRNET-BUC & 38.4009 & 27.1516 & 3.27 & 258 & 468 \\
\hline 45 & 3525 & IZMIRNET-YSL & 38.3723 & 27.1084 & 3.86 & 258 & 745 \\
\hline 46 & 1008 & BIGADIC & 39.39786 & 28.12733 & 16.28 & 259 & 300 \\
\hline 47 & 1633 & KARACABEY & 40.21397 & 28.36262 & 17.73 & 259 & - \\
\hline 48 & 4502 & AKHISAR & 38.91121 & 27.82326 & 14.4 & 261 & 292 \\
\hline 49 & 3511 & IZMIRNET-PNR & 38.4213 & 27.2563 & 3.37 & 262 & 827 \\
\hline 50 & 4507 & TURGUTLU & 38.50748 & 27.7061 & 6.22 & 282 & - \\
\hline 51 & 3532 & TORBALI & 38.15911 & 27.35956 & 8.64 & 290 & - \\
\hline 52 & 3531 & BAYINDIR & 38.22026 & 27.64853 & 1.93 & 301 & - \\
\hline 53 & 3509 & ODEMIS & 38.21565 & 27.9645 & 10.48 & 321 & 286 \\
\hline
\end{tabular}

In the first 48 hours after the earthquake, 405 aftershocks were ocurred with magnitudes between 1.1 and 5.3 [16]. It was tried to select earthquakes recorded by all stations and $\mathrm{M}>4$ good signal-tonoise $(\mathrm{S} / \mathrm{N})$ ratio among them. The epicentral locations are shown in Figure 1 , and location parameters are listed in Table 1 . Local magnitudes vary from 4 to 6.5, and focal depths are between 7 and $26 \mathrm{~km}$. Epicentral distances vary between 51 and $321 \mathrm{~km}$. The maximum epicentral distance between reference site (BYR) and other stations is76 km (with ODEM station deployed at the southeastern extremity of the study area). All epicentral distances are less than their hypocentral distances from the sources. Therefore, it is probably a good assumption that the path effects on the records are similar.

The success of the standard spectral ratio technique relies on the availability of a good reference station. Site effect may affect ground motion even on hard rock as discussed in detail by [17]. As already noted, the BYR reference site chosen in this study was located on hard Miocene andesite outcrop. Figure 2 shows accelerograms of the main-shock which was recorded at all sites. 
Amplitudes are much higher, and durations are longer at other sites compared to the reference station, as was also typically observed for other earthquakes. As seen in the figure, the frequency content of the DKL is quite different from the BRN and KSK stations. As expected, the rock site BYR, located in NE of Izmir Bay, has the smallest amplitudes, and the soil site DKL has remarkably high amplitudes as compared with other three sites.

Processing of signals is as follows. Accelerograms were corrected for system response, and spectral amplitudes were computed. Different time window lengths were used for each event, starting $3 \mathrm{~s}$ before and ending 7$10 \mathrm{~s}$ after the $\mathrm{S}$ arrival.

This ensured that S-wave was included. The acceleration Fourier spectra were smoothed using the [18] algorithm, fixing the smoothing parameter $b$ to 20 . A cosine taper was applied to over the $10 \%$ of each record before taking the Fourier transform. The average horizontal spectrum was computed by adding the squared moduli of the horizontal spectra before taking the square root. Spectra were smoothed by a simple moving average filter.
Moreover, site response was estimated using H/V technique [14], as well. This technique is a good tool to determine the fundamental soil frequency and to reveal site characteristics. The basic assumption of this method is that the vertical component is not influenced by the local site geological structure, whereas the horizontal components contain the local geological properties underlying the recording site. Site response is obtained by deconvolving the vertical component from the horizontal component. In the frequency domain, this corresponds to the division of horizontal spectrum by the vertical spectrum $(\mathrm{H} / \mathrm{V})$. This approach had been firstly applied to the microtremor data by [8]. Experimental studies using this technique showed some encouraging results, suggesting the possible use of this technique for the microzonation studies. Simultaneously, these studies suggested that such $\mathrm{H} / \mathrm{V}$ ratio analysis might be meaningful not only for microtremor measurements but also for weak-motion recordings, although questions are still unresolved about the validity of the ground-motion amplification factors obtained by this technique $[2,19]$. 

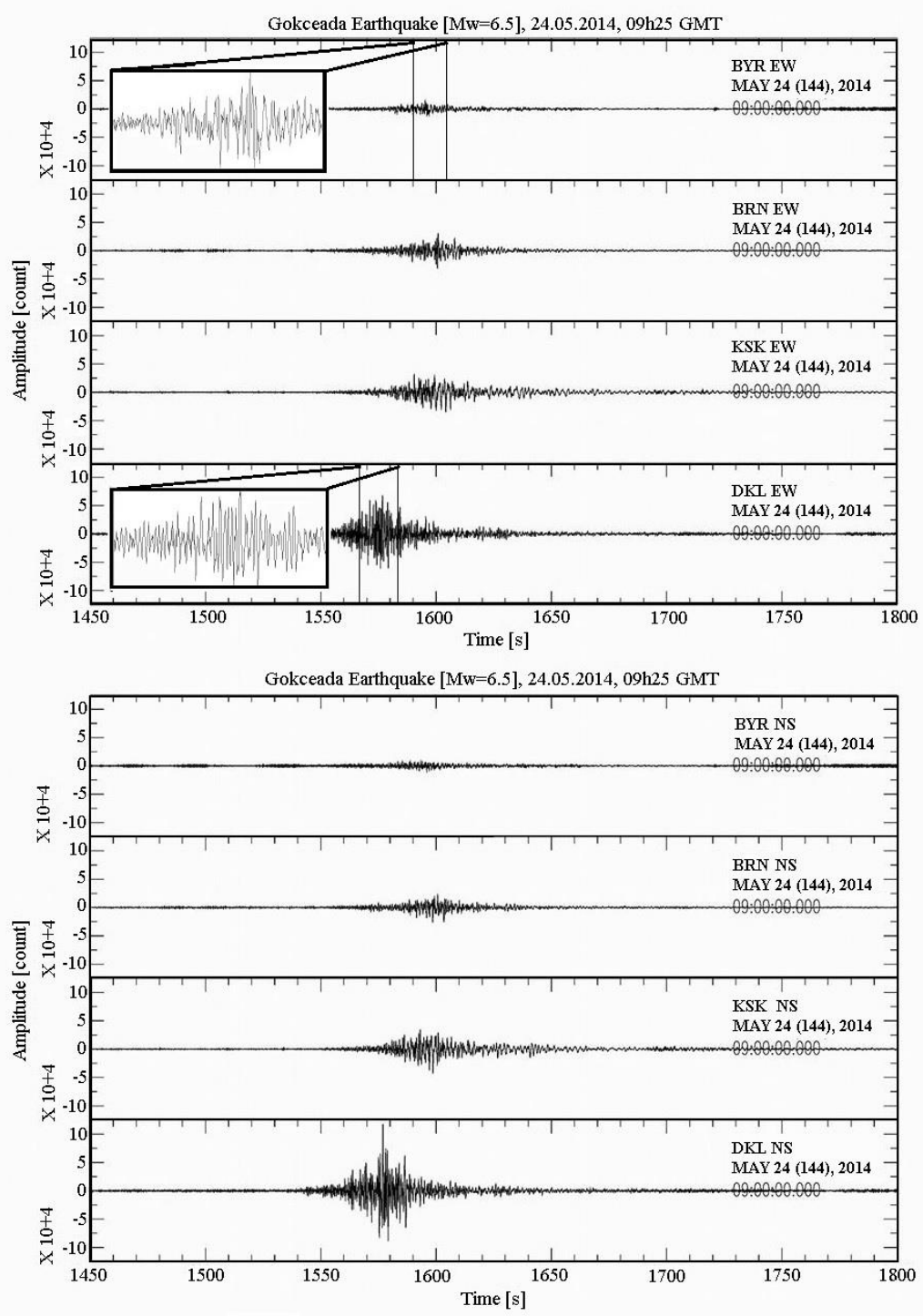

Figure 2. Comparison of three-component unfiltered accelerograms for the mainshock recorded at four sites, including reference site BYR. (a) East-West component (b) North-South component. All accelerograms are fitted to the same scale.

In this study, we use main-shock and eight aftershocks to obtain the site features of the study area calculated by SSR and $\mathrm{H} / \mathrm{V}$ techniques at 16 stations (Figure 3). We also use twelve AFAD triggered stations to figure out for only mainshock. In Figure 3, thick lines and dashed lines represent the main-shock of Gokceada Island Earthquake, the thick line also represent the results of the SSR and dashed curves are the results of the $\mathrm{H} / \mathrm{V}$ method and the subtle lines are the other aftershocks. Some continuous stations (IzmirNET) show remarkable amplifications. In particular, DKL and KSK have a strong amplification peaks at a low frequencies in both SSR with EW and NS component and $\mathrm{H} / \mathrm{V}$ methods. 
E. Gok / The Gokceada Island (Northwest of Turkey) Earthquake of Mw 6.5 on 24 May 2014: Strong-Motion Examinations

The similar results are observed for the stations; BYN, CMD, BRN, BOS, URL and BLC where amplifications peak at low frequencies $(0.5-0.7 \mathrm{~Hz})$ are evident for the alluvial deposits. Some fluctuations were observed at some sites, especially the results of $\mathrm{H} / \mathrm{V}$ at GZL and KON stations which are also located on the alluvial units. 
E. Gok / The Gokceada Island (Northwest of Turkey) Earthquake of Mw 6.5 on 24 May 2014: Strong-Motion Examinations
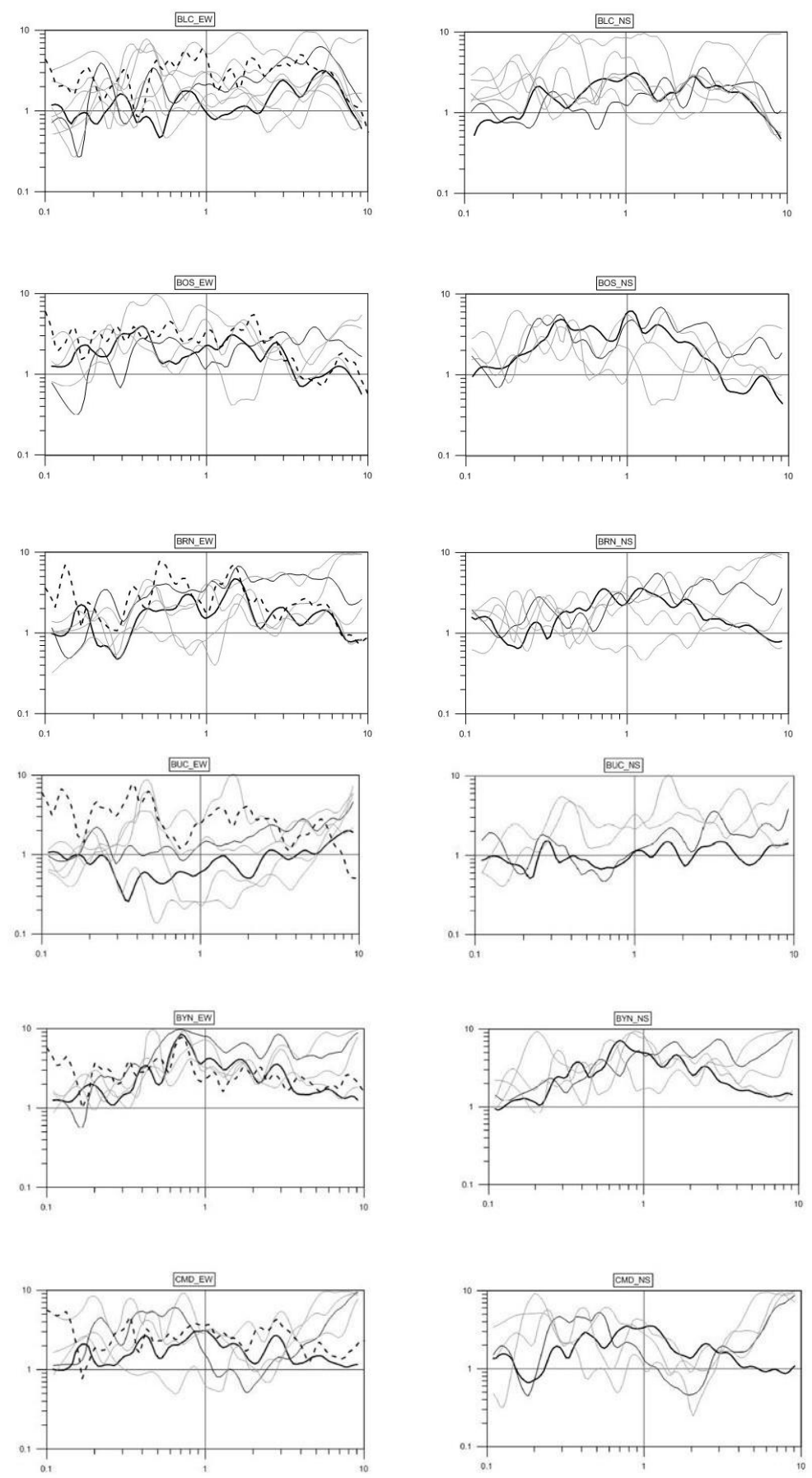

Figure 3. Comparison of the $\mathrm{S}$-wave spectral ratio at each site relative to the reference site, using the SSR method for IzmirNET stations. The thick lines represent the results of the SSR and dashed curves are the results of the H/V method. 
E. Gok / The Gokceada Island (Northwest of Turkey) Earthquake of Mw 6.5 on 24 May 2014: Strong-Motion Examinations
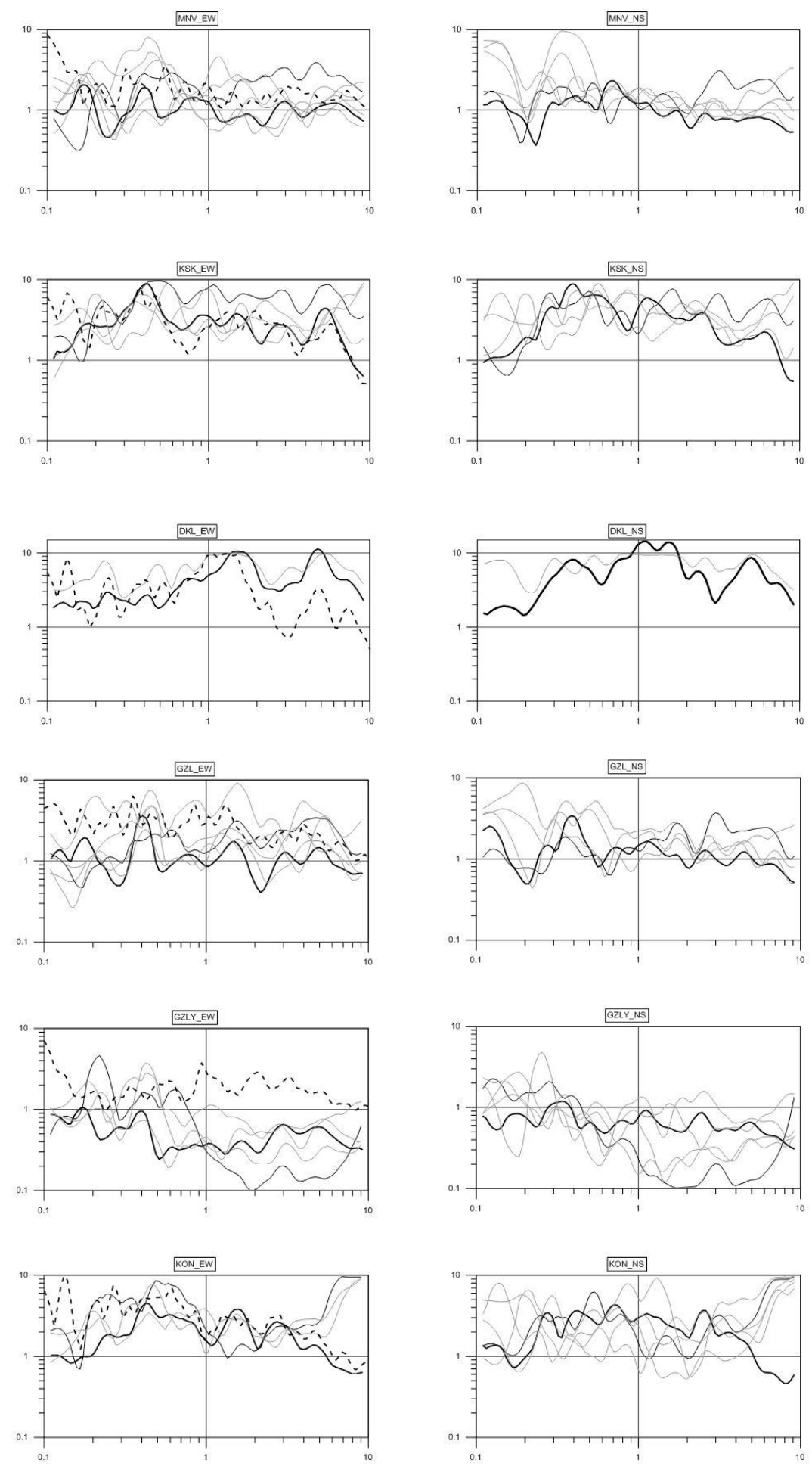

Figure 3. Continued. 

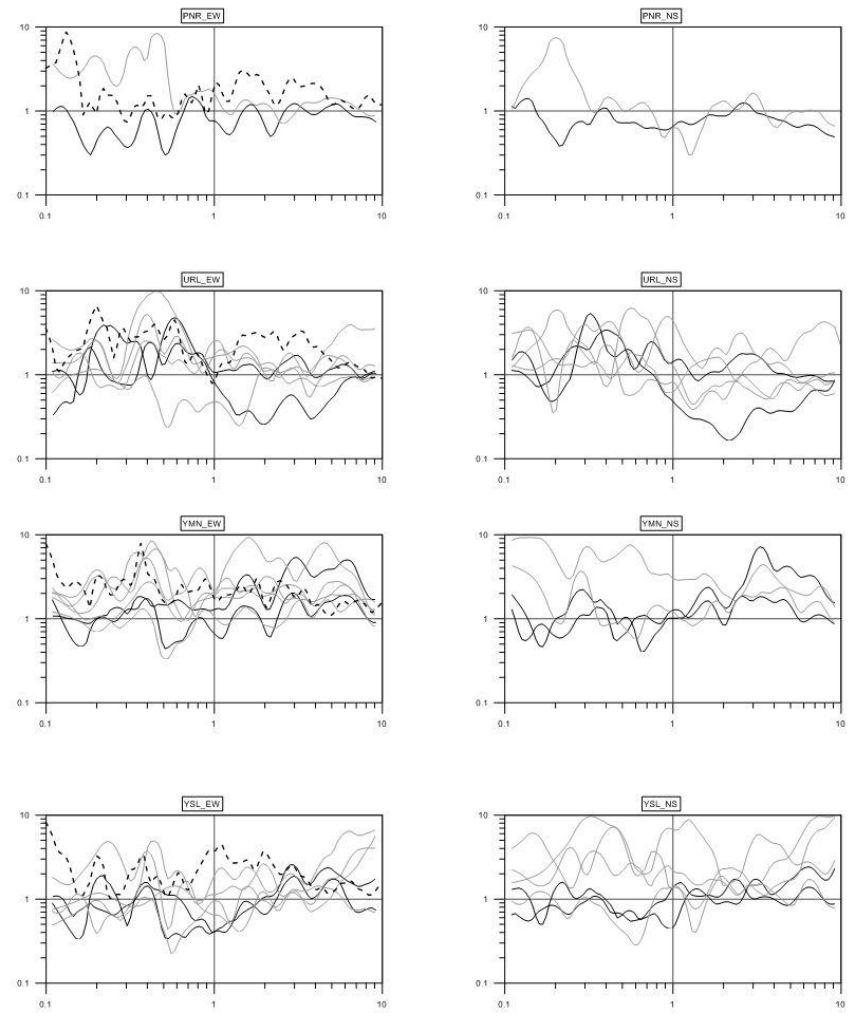

Figure 3. Continued.

Although the stations installed on volcanic units (MNV, YMN) have variable $\mathrm{H} / \mathrm{V}$ curves, the results of SSR show low amplifications. On limestone units; YSL station shows low amplification at high frequency, PNR also has no amplification on NS component. The incompatibility of some stations between the results of $\mathrm{H} / \mathrm{V}$ and SSR was observed. In particular, GZLY and BUC sites show amplifications at low frequencies in $\mathrm{H} / \mathrm{V}$ results although the SSR has no amplification. Moreover, the spectral ratios of triggered stations for the main-shock of the Gokceada Island Earthquake were calculated (Figure 4). It could not find a good signal to noise ratio to help support the results of the spectral ratios with aftershocks. Because of this, only the result of main-shock was used. MENEM site shows a distinctive amplification for both methods of SSR and H/V. Particularly, NS component of this station has a broad frequency range and the amplitude exceeds the selected limits of the axis. At CESM site, a high $\mathrm{H} / \mathrm{V}$ value at low frequency was observed but the results of SSR show opposite both EW and NS component. When we consider the location of the station, we can expect the amplification. However, if SSR result is not shown, $\mathrm{H} / \mathrm{V}$ peaks detected at such low frequencies should be ignored. Some stations, such as ALI and TORB exhibit nearly the same results except their component of NS. If we had Vs $\mathrm{s}_{30}$ values of these stations, we could make more accurate comments. In this case, more earthquakes are needed to evaluate. High amplifications at low frequencies were observed. On the contrary, no clear amplification peak was observed at the BAYN, BERG, and KINK stations. KARB and ODEM sites have no reliable results for $H / V$, however, they show low amplification values around $1 \mathrm{~Hz}$. 

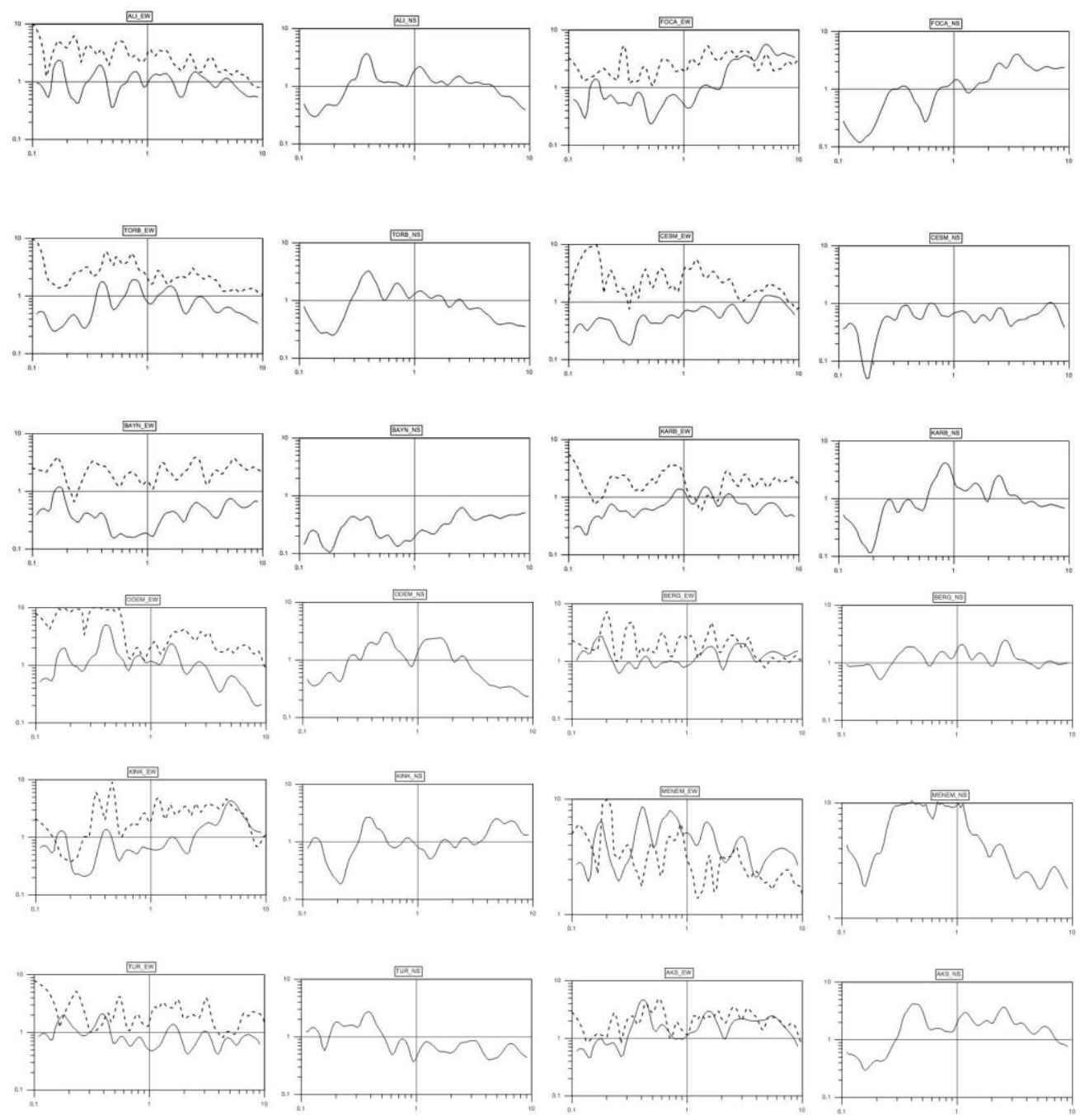

Figure 4. Comparison of S-wave spectral ratio at each site relative to the reference site, using the SSR method for Triggered AFAD stations. The thick lines represent the results of the SSR and dashed curves are the results of the H/V method.

\subsection{PGA of the ground motion}

An overview of the spatial variability of ground motion recorded in the epicentral area is illustrated in Figure 5 where the maximum horizontal PGA values have been interpolated. The data interpolation was executed by the Kriging algorithm [20], which predicts unknown values using variograms to precise the spatial variation and minimizes the error of predicted values.
Note that the PGA contours are extended in the east-west direction. The highest recorded PGA was at Gokceada station (176.6 gal at horizontal component), located about $51 \mathrm{~km}$ from the surface rupture. Iso-acceleration contours are presented in Figure 5. As the figure shows, the attenuation of PGA with the distance from the epicenter is reduced to the southwest. Moreover, the most affected area corresponding to the PGA range $130-180 \mathrm{~cm} / \mathrm{s}^{2}$ stretches to the 
E. Gok / The Gokceada Island (Northwest of Turkey) Earthquake of Mw 6.5 on 24 May 2014: Strong-Motion Examinations

northeast, possibly indicating directivity effects in the rupture propagation along the NAF. Ground-motion amplitude values decrease faster toward the southeast than toward the southwest. This decrease can be interpreted as an asymmetric attenuation of PGA. Depending on this, it can be said that propagation effect has a significant role in defining the ground-motion instability in the area.

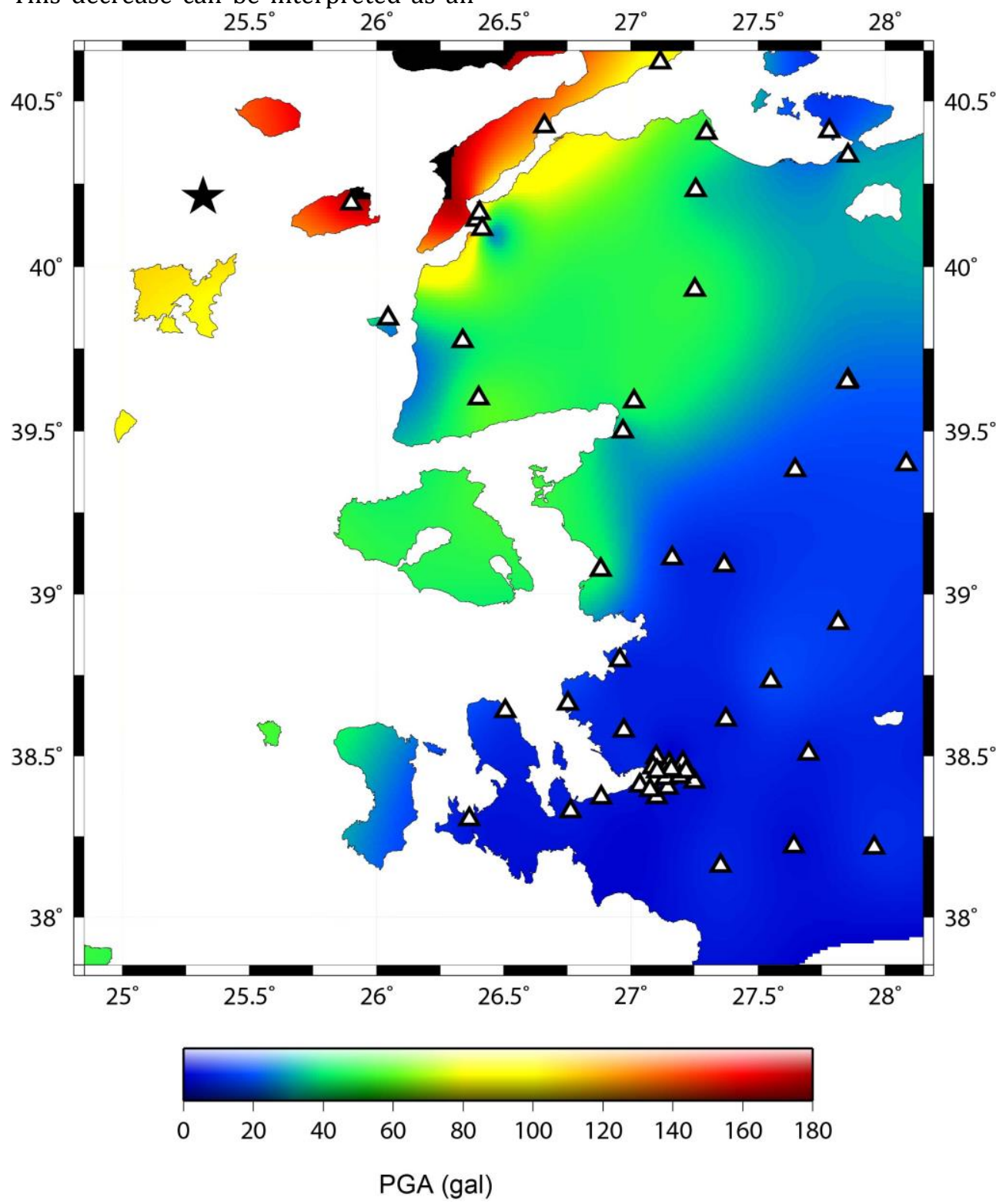

Figure 5. Peak ground acceleration map for the 24 May 2014 Mw 6.5 Gokceada Island (Northwestern of Turkey) Earthquake. Triangles show the location of the stations that used in this study. The star indicates the earthquake epicenter. 


\section{Results}

The attenuation with the distance of the peak ground accelerations observed during the mainshock is compared with the predictions of global and regional models: [21-24] based on Turkey, Western Anatolia and Marmara Region data, respectively; and [24] based on the European data set. This comparison is useful for understanding the average characteristic of the Gokceada earthquake ground motion and validating predictive models exploiting data sets with different magnitude and distance ranges for different site characteristics. Figure 6 shows four different GMPEs for different site conditions. In figure 6, black triangles present the observed PGA for mainshock. We compared the measured PGA to GMPEs. The panels represent EC8 site classes (A, B, C, and D). An equivalent EC8 class is used for the GMPEs adopting different soil parameterization depending on the values of Vs30. At distances larger than $200 \mathrm{~km}$ PGAs show a fast decay. Nearly all the PGA values are above the GMPEs for $R J B$ between $50 \mathrm{~km}$ and $200 \mathrm{~km}$. Since the PGA values measured at the stations and the GMPE models do not correspond directly, at least some RJB distances have been compared.The near-fault PGAs $(R J B=50$ $\mathrm{km}$ and $80 \mathrm{~km}$ ) are better fit by [22] for all sites. However, this model used for Western Anatolia was insufficient compared to the PGA values measured after $80 \mathrm{~km}$.The model of [21] shows consistency for $R J B$ values 100 and $200 \mathrm{~km}$. At all sites, higher PGA values than the equation of [23] for less than $200 \mathrm{~km}$ were observed except for $90 \mathrm{~km}$. The equation of [24] best fits on between $70 \mathrm{~km}$ on site A, and $100 \mathrm{~km}$ on site B $90 \mathrm{~km}$ on site $\mathrm{C}$ and $\mathrm{D}$ for only one station. Compared to the measured PGA values and GMPEs, high PGA values were obtained from GMPEs, especially at close distances. 


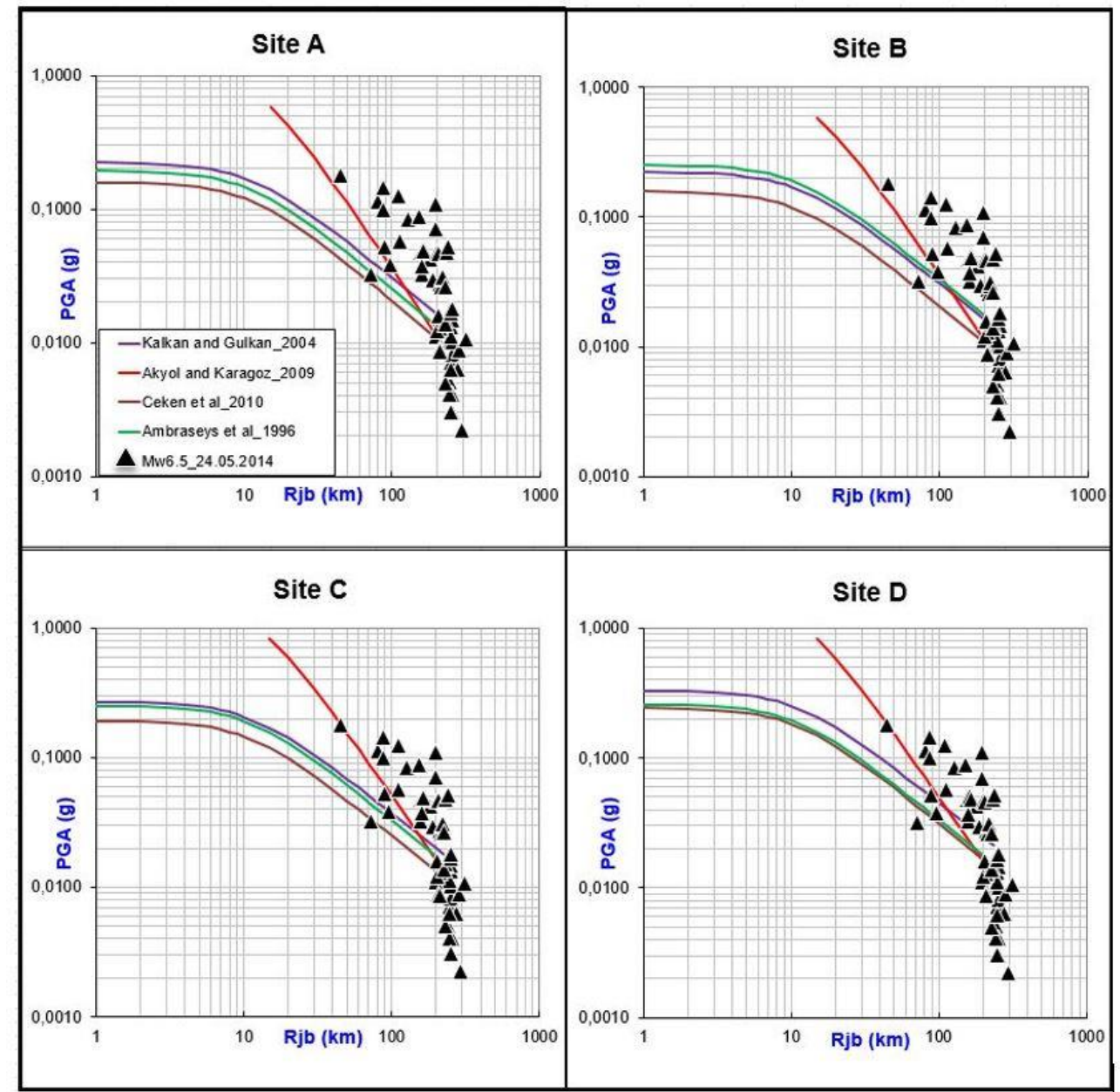

Figure 6. Peak ground acceleration for maximum horizontal component versus Joyner and Boore distance $(R J B)$. Data are separated according to EC8 site classification and compared with different GMPEs. Purple, red, brown, green lines show respectively the models $[21,22,23,24]$. Black triangle represents Gokceada Island earthquake.

Generally, there is a good agreement in the shape of the H/V and SSR curves at the location of the peaks and the amplification level. Some stations (YMN and MNV) located on volcanic sediments have clear peaks that may be related to higher frequencies in the $\mathrm{H} / \mathrm{V}$ and SSR curves with amplifications even exceeding 3. Despite the variability of two methods, the $\mathrm{H} / \mathrm{V}$ results may provide the higher bound level of amplification with respect to the SSR results. In particular, the results of $\mathrm{H} / \mathrm{V}$ at lower frequencies are exaggerated in comparison with the SSR results. However, the H/V method fails to detect amplification at lower frequencies, below $1.0 \mathrm{~Hz}$. Our results suggest that SSR is more reliable than $\mathrm{H} / \mathrm{V}$ according to the known geological conditions.

\section{Discussion and Conclusion}

The 24 May 2014 Gokceada Island Mw 6.5 earthquake and its aftershocks come 
out to be the most extensive set of strong-motion data in the around and near-source region. An analysis of instrumental data indicates the maximum peak ground acceleration observed at Gokceada island station. The mainshock was recorded by 53 strongmotion stations belonging to the AFAD, with 29 of these located around Izmir city. The available data set is composed of more than 300 three-component strong-motion records from $M w \geq 4$ events recorded by IzmirNET and AFAD stations.

The site response for the continuous (IzmirNET) and triggered stations were also analyzed based on SSR and H/Vs. A comparison of the observed acceleration response spectra shows that the nearfault motion generally exceeded the average of all motion data limit both for horizontal and vertical components. Figure 3 and 4 illustrate results for SSR relative to BYR and H/V at 29 sites. The resonance frequency peaks for the stations deployed on quaternary alluvial deposits are consistent with the conventional site categories of the EC8.

Significant amplifications (i.e., exceeding 2) are observed in the SSR curves at the stations located on limestone and sandstone sediments (YSL, PNR, BUC) for frequencies higher than the fundamental one. In fact, the results from both the $\mathrm{H} / \mathrm{V}$ and SSR methods correspond well at $1 \mathrm{~Hz}$ and higher of the frequency band.

In general, the results of amplification and PGA values are convenient (e.g. DKL station). DKL station with the highest value in the IzmirNET has high amplification values of both $\mathrm{H} / \mathrm{V}$ and SSR methods. Despite the low PGA value at MENEM site, amplifications are remarkably high. Also, the attenuation relationships for the mainshock are compared using global and regional models. The PGA values recorded at the accelerometer stations are not directly consistent with the GMPEs. Observed PGA values were significantly higher than the prediction models. The prediction models are inadequate to explain the differences of PGA depending on distance. Ground motion of the Gokceada Island Earthquake causes higher PGA than predicted.

In Izmir, the maximum amplifications are seen at low frequencies on the alluvial sites for both SSR and H/V methods. Fundamental frequencies of the soils and the fundamental frequencies of the buildings are mutually close in the city. Since our analysis identifies the resonance effects, i.e., soilstructure or ground motion-soilstructure, they can play an important role in case of a future earthquake, and contribute significantly to the damage in the area.

\section{Acknowledgements}

The GMT [25], SAC [26] and Geopsy (http://www.geopsy.org) software packages were used to generate most figures. I would like to thanks to the editorial board and reviewers of Dokuz Eylul University Journal of Science and Engineering for their valuable opinion and contributions. This paper has been spellchecked and grammar-checked by Ugur Ozdemir (www.ideatercume.com). 


\section{References}

[1] Bozkurt, E., 2001. Neotectonics of Turkey, a Synthesis. Geodinamica Acta 14, 3-30.

[2] Ozel, O., Cranswick, E., Meremonte, M., Erdik, M., Safak, E., 2002. Site Effects in Avcilar, West of Istanbul, Turkey, from Strong- and WeakMotion Data. Bull. Seism. Soc. Am. 92 (1), 499-508.

[3] Polat, O., Gok, E. and Yilmaz, D., 2008. Earthquake Hazard of Aegean Extension Region, Turkey. Turkish J. Earth Sci. 17, 593-614.

[4] Gok, E., Chávez-García, F.J. and Polat, 0. 2014. Effect of soil conditions on predicted ground motion: case study from Western Anatolia, Turkey, Phys. Earth Plan. Int. 229, 88-97.

[5] Polat, O., Ceken, U., Uran, T., Gok, E., Yilmaz, N., Beyhan, M., Koc, N., Arslan, B., Yilmaz, D., Utku, M., 2009. IzmirNet: A Strong-Motion Network in Metropolitan Izmir, Western Anatolia, Turkey. Seism. Res. Lett. 80 (5), 831-838.

[6] Boore, D.M., Seekins, L., Joyner, W.B., 1989. Peak acceleration from the 17 October 1989 Loma Prieta earthquake. Seism. Res. Lett. 60, 151-166.

[7] Borcherdt, R.D., 1970. Effects of local geology on ground motions near San Francisco Bay. Bull. Seism. Soc. Am. 60, 29-61.

[8] Nakamura, Y., 1989. A method for dynamic characteristics of estimation of subsurface using microtremor on the ground. Q. Rep. RTRI 30, 1.

[9] Chavez-Garcia, F.J., Pedotti, G., Hatzfeld, D., Bard, P.-Y., 1990. An experimental study of site effects near Thessaloniki (Northern Greece). Bull. Seism. Soc. Am. 80, 784-806.

[10] Lachet, C., Hatzfield, D., Bard, P.Y., Theoduludis, N., Papaiannou, C. and Alekos, S., 1996. Site effects and microzonation in the city of Thessaloniki (Greece) Comparison of Different Approaches. Bull. Seism. Soc. Am. 86, 1692-1703.

[11] Bindi, D., Parolai, S., Spallarossa, D., Cattaneo, M., 2000. Site effects by $\mathrm{H} / \mathrm{V}$ ratio: comparison of two different procedures. J. Earthqu. Eng. 4, 97-113.

[12] Parolai, S., Bindi, D., Baumbach, M., Grosser, H., Milkereit, C., Karakisa, S., Zünbül, S., 2004a. Comparison of different site response estimation techniques using aftershocks of the 1999 Izmit Earthquake. Bull.Seismol Soc Am 94-3:1096-1108.

[13] Parolai, S., Richwalski, S.M., Milkereit, C., Bormann, P., 2004b. Assessment of the stability of $\mathrm{H} / \mathrm{V}$ spectral ratios from ambient noise and comparison with earthquake data in the Cologne area (Germany). Tectonophysics 390,57-73 (special issue on strong ground motion, earthquake hazard and risk in Alpine-Himalayan and Pacific Regions)

[14] Lermo, J., Chavez-Garcia, F.J., 1993. Site effect evaluation using spectral ratios with only one station. Bull. Seism. Soc. Am. 83 (5), 1574-1594.

[15] Yalçinkaya E., 2005. Bytnet (Bursa-Yalova-Turkey İvme Ölçer Ağı) Istasyonlarında Yerel Zemin Etkilerinin Incelenmesi", Fen ve Mühendislik Dergisi, ss.75-86

[16] AFAD ， 2014. 24/05/2014 Gökçeada açıkları Ege Denizi depremi ön raporu. https://www.afad.gov.tr/upload/ Node/3929/xfiles/ege-denizidepremi-on-raporu-r.pdf

[17] Buech, C.I.D., Michel, A. and Sonntag, K., 2010. Suggestion Systems in Organizations: what Motivates Employees to Submit Suggestions? European Journal of 
E. Gok / The Gokceada Island (Northwest of Turkey) Earthquake of Mw 6.5 on 24 May 2014: Strong-Motion Examinations

Innovation Management, vol.13, no.4, Pp 507-525.

Seismology, Academic Press, London.

[18] Konno, K., Ohmachi, T., 1998. Ground-motion characteristics estimated from spectral ratio between horizontal and vertical components of microtremor. Bull. Seism. Soc. Am. 88, 228-241.

[19] Ergin, M., Ozalaybey, S., Aktar, M., Yalcin, M.N., 2004. Site amplification at Avcilar, Istanbul. Tectonophysics 391, 335-346.

[20] Davis, J.C., 1973. Statistics and Data Analysis in Geology. Wiley, New York, N.Y., 550 pp.

[21] Kalkan, E. and Gulkan, P., 2004. Site-dependent spectra derived from ground-motion records in Turkey, Earthq. Spectra, 4, 11111138

[22] Akyol, N., and Karagöz, Ö., 2009. Empirical attenuation relationships for western Anatolia, Turkey. Turkish Journal of Earth Sciences, 18:351-382.

[23] Ceken, U., Beyhan, G. and Polat, O., 2010. Ground-motion prediction equations for strong ground motion in Marmara region, NW Anatolia of Turkey, Phys.Earth Planet.Int. (in revision).

[24] Ambraseys, N. N., Simpson, K. A. and Bommer, J. J., 1996. Prediction of Horizontal Response Spectra in Europe, Earthquake Engineering and Structural Dynamics, Vol. 25, 371-400.

[25] Wessel, P, Smith, W.H.F., 1995. New version of the Generic Mapping Tools (GMT). EOS Transactions 76, 329.

[26] Goldstein, P., Dodge, D., Firpo, M., Minner, L., 2003. The SAC2000: Signal processing and analysis tools for seismologists and engineers, In: Lee, W.H.K., Kanamori, H., Jennings, P.C., Kisslinger, C. (Eds.), The IASPEI International Handbook of Earthquake and Engineering 